It is necessary that abstracts of all papers to be read in the Section should be sent to us before the 15 th of July.

\author{
Grorge E. Shuttleworth, M.D., \\ Royal Albert Asylum, Lancaster. \\ Wy. Julius MickLe, M.D. \\ Grove Hall, Bow, London, W.
}

N.B.-No Paper must occupy more than 15 minutes in reading, and subsequent speeches are limited to 10 minutes.

\title{
AFTER-CARE.
}

The Association for tile After-Care of Poor and Frifndegs Female Convalescents on Leaving Asyluys ror the Insane.

The Anniversary Meeting for 1883 will be held, by the kind permission of Lord Cottesloe, at 20, Eaton Place, on Thursday, 5th July, at Throe p.m.

Rev. H. Hawkiss,

Chaplain's House, Colney Hatch, N.

Obituary.

M. LASEGUE.

The distinguished Professor of Clinical Medicine in the Faculté de Médecine, in Paris, and Physician-in-Chief of the Insane Infirmary of the Prefecture of Police, died March 20th, 1883, aged 67. He was an honorary member of our Association. The memory of M. Lasegue must be fresh in the memory of all who were present at the Section for Mental Diseases of the International Congress in London two years ago. Everyone listened to his discourse on epilepsy with pleasure, whether his original views carried conviction with them or not. With few Frenchmen did the flexibility and beauty of their language appear to greater effect. His power of description, aided by rapid and effective sketches on the black-board, was unsurpassed, and those who had the pleasure of his acquaintance in Paris knew what an admirable clinical teacher he was. A dash of humour would again and again relieve and enliven his statement of scientific facts. On the occasion referred to it will be remembered that $M$. Lasegue, in mentioning incidentally the fact that the patient of whom he was speaking had nine children, laughingly exclaimed, "Famille Anglaise !" At the annual dinner of our Association, 1881, he responded to the toast proposed by the President, "Our Foreign Guests."

M. Lasègue was an accomplished physician in all departments of medicine, although especially distinguished in mental disorders, and was in 1870-71 President of the Société-Médico-psychologique of Paris, to which body M. Motet, who now worthily fills that office, thus expressed himself at the séance of the 9th April last. " From whatever side we study this truly remarkable man, we are struck with the perfection of the qualities by which he was distinguished. As Clinical Professor in the Faculté de Médecine, he conducted his teaching with the greatest care. His lessons which were not written, but which he had long studied, were models of able exposition. Full of facts und clever insight, they were for the student a sort of initiation to unknown and even unsuspected truths. For those who, more experienced, listened to the master, they were the long-sought solution of questions previously unsolved. Lasègue spoke and as he proceeded to formulate his idea, it was a revelation for him who was able and knew how to comprehend it. There was not a word, not a phrase, to which our previous thoughts did not responil and which did not state in terms of admirable precision the law of pathological conditions, glimpsed at before perhaps, 
but never determined as they were by him. . . For us, gentlenen, in whose midst he took his place in 1867 , too late according to our wishes, he was already known as one of ourselves by the writings with which he had enriched your 'Annales.' From the first he was one of the collaborateurs with his friend Morel. The historical studies on insanity, on its moral treatment, on certain asylums in Russia, belong to the period of 1844-1848. And subsequently the 'Archives Générales de Médecine,' as well as your 'Annales' are full of these monographs, wherein pages of vigorous brevity are condensed studies of the highest scientific value. Need I recall to you that chef d'cuvre of fine analysis called 'Le Délire de Persécution?' Published in February, 1852, the original memoir of Lasègue has circulated, we may say, throughout the scientific world. Everywhere this form, the outlines of which have been traced with so forcible a pen, has been accepted ; nothing has been added to it, so precise was the description, the details of which had all been supplied by clinical observation. It has been the same with all Lasègue's works, and you know that they are numerous. From predilection he attached himself to Mental Medicine, into which he had been initiated by a master, a friend, the elder Falret. . . . Lasègue was a high authority in medicolegal questions. He owed this not less to the recognised independence of his character than to his great knowledge. He judged things from a height, with a precision, a nicety, which carried conviction. His concise reports, in a form sometimes aphoristic, expressed all that was necessary, and nothing more. We, his former colleagues, shall recall the part which he took at our discussions we shall never forget what he was during our Congress of 1878 , where, side by side with our venerated President, M. Baillarger, he appeared as one of the most distinguished representatives of Mental Medicine in France."

We regret that our space does not allow us to cite the whole of M. Motet's discourse, which is as true as it is eloquent.

Since the above was in type we have received from him a few particulars, which we subjoin :- " Charles Lasègue was born in Paris, Sept. 5, 1816. It was not intended he should follow Medicine, but forming a friendship with Claude Bernard and Morel he acquired a taste for Medical Science, and began to study it in consequence. It was at the Salpêtrière, in the wards of $\mathbf{M}$. Falret pére, that he applied himself to mental alienation, for which he was prepared by his psychological knowledge; and he became the favourite pupil, and then the friend of both Falret and Voisin. At the time of his death he was physician to the Hospital of La Pití (as well as holding the appointments mentioned above) Lasegue died in the midst of his family, whom he so much loved. He was a man of the warmest affections, and faithful in his friendships. I do not speak of his superior intelligence ; you know that as well as I do. His loss is acutely felt by all those who had the honour of his acquaintance."

\section{HERVEY B. WILBUR, M.D.}

The death is announced of Dr. H. B. Wilbur, for upwards of 30 years Superintendent of the New York State Idiot Asylum. On May 1st he suffered from sudden attack of illness whilst writing at his desk, and after rallying for a short time was seized with fatal syncope, the autopsy disclosing extensive fatty degeneration of the heart.

Dr. Wilbur was born in 1820, and was educated at Amherst College. After engaging for a time in the work of teaching, he studied civil engineering, but moon abandoned this field in order to study medicine. He possessed qualities that were admirably suited to this profession, in which he was successful from the start, in Lowell first, and afterwards at Barre. He was one of the first in America to turn attention to the care and rational treatment of idiots, and having made vain efforts to enlist the support of gentlemen of means, he received pupils in his house, and commenced in a humble way a work that was destined to com. 